\title{
ANALISIS SIKAP KELUARGA DALAM PENERAPAN PROGRAM INDONESIA SEHAT DENGAN PENDEKATAN KELUARGA (PIS-PK)
}

\author{
Ifon Driposwana Putra1 ${ }^{1)}$, Ulfa Hasana ${ }^{2)}$ \\ ${ }^{1,2}$ DIII Keperawatan, STIKes Payung Negeri Pekanbaru, Jalan Tamtama No 6 Pekanbaru \\ Email :ifondriposwanaputra@gmail.com
}

Diterima: Desember 2019, Diterbitkan: Desember 2019

\begin{abstract}
ABSTRAK
Kementerian Kesehatan telah menetapkan bahwa strategi operasional pembangunan kesehatan adalah melalui Program Indonesia sehat dengan pendekatan keluarga (PIS-PK), dengan tujuan untuk meningkatkan derajat kesehatan dan status gizi masyarakat yang dimulai dari pendekatan yang berbasis dasar, yaitu keluarga. Namun dalam penerapannya, program ini belum membuahkan hasil yang maksimal yang dibuktikan dengan masih rendahnya derajat kesehatan di masyarakat, khususnya di wilayah kerja puskesmas sail kota pekanbaru dengan persentase $24,85 \%$ rumah tangga yang berperilaku hidup bersih dan sehat (PHBS), padahal petugas kesehatan secara berkesinambungan selalu diberikan pelatihan dalam menjalankan program ini. Oleh karena itu, tujuan dari penelitian ini adalah untuk menganalisa sikap keluarga dalam penerapan program Indonesia sehat dengan pendekatan keluiarga (PIS-PK). Jenis penelitian ini adalah deskriptif analitik dengan 100 responden dan menggunakan analisa univariat. Instrumen yang digunakan adalah instrumen Indeks Keluarga Sehat (IKS). Hasil analisis tentang sikap keluarga dalam penerapan PIS-PK diperoleh bahwa lebih dari separoh persentase keluarga bersikap positif yaitu 66\%. Disarankan kepada petugas puskesmas untuk lebih giat mensosialisasikan indikator-indikator PIS-PK untuk dapat diterapkan oleh keluarga agar tercapainya keluarga sehat (KS).
\end{abstract}

Kata Kunci: Sikap, Program Indonesia Sehat, Keluarga

\begin{abstract}
The Ministry of Health has determined that the operational strategy for health development is through the Healthy Indonesia Program with a family approach (PIS-PK), with the aim of improving the health status and nutritional status of the community starting from a basic-based approach, which is the family. However, in its implementation, this program has not produced maximum results. The study showed low level of health in the community, especially in the working area of Pekanbaru City Sail Puskesmas. Only $24.85 \%$ of households are behaving clean and healthy even though regular program from health workers on training in carrying out this program. Therefore, the purpose of this study was to analyze the attitudes of families in implementing a healthy Indonesia program with the family approach (PIS-PK). This type of research was descriptive analytic with 100 respondents and uses univariate analysis. The instrument used was the Healthy Family Index instrument. The analysis of family attitudes in implementing PIS-PK showed that more than half the percentage of families were positive at $66 \%$. It is recommended to health center staff to more actively socialize PIS-PK indicators to be applied by families so that healthy families can be achieved.
\end{abstract}

Keywords: Attitudes, Healthy Indonesia Program, families.

\section{PENDAHULUAN}

Sasaran pembangunan kesehatan yang akan dicapai pada tahun 2025 adalah meningkatnya derajat kesehatan masyarakat. Tujuan dan sasaran pembangunan kesehatan ini dapat dilakukan dengan menerapkan strategi pembangunan kesehatan, dan untuk menjawab tantangan pembangunan kesehatan tersebut haruslah berfokus kepada pendekatan program dan pendekatan keluarga yang diinisiasi dengan pemetaan atas permasalahan mendalam 
dari pendekatan siklus hidup melalui kunjungan rumah. Pendekatan dengan kunjungan rumah akan dapat mengenali masalah-masalah kesehatan yang dihadapi keluarga dan pola perilaku hidup bersih dan sehat dari keluarga (Kemenkes RI, 2016).

Dinas Kesehatan Kota Pekanbaru Tahun 2017 telah melakuan pendataan terhadap 20 Puskesmas yang tersebar di Kota Pekanbaru. Data yang didapatkan yaitu dari 245.389 Jumlah Rumah Tangga di 20 Puskesmas Kota Pekanbaru dilaporkan bahwa Rumah Tangga di wilayah Kerja Puskesmas Sail Pekanbaru adalah persentase rumah tangga berperilaku hidup bersih dan sehat (Ber-PHBS) yang paling rendah yaitu $24,85 \%$ dari 5.216 Jumlah rumah tangga.

Program Indonesia sehat dengan pendekatan keluarga (PIS-PK) yang telah diinisiasi oleh pemerintah diharapkan mampu meningkatkan derajat kesehatan masyarakat melalui upaya kesehatan dan pemberdayaan masyarakat. Program Indonesia sehat telahdisepakati adanya 12 indikator utama untuk penanda status kesehatan sebuah keluarga atau cermin dari kondisi PHBS dari keluarga tersebut (PeraturanMenteriKesehatan RI, 2016).

Faktor yang mempengaruhi terbentuknya perilaku seseorang, menurut Green (1980 dalam Notoatmodjo, 2007) yaitu Predisposing Factors, faktor ini mencakup pengetahuan dan sikap terhadap kesehatan, tradisi, dan kepercayaan masyarakat terhadap hal-hal yang berkaitan dengan kesehatan dan sebagainya.

Tujuan umum dari penelitian ini adalah untuk menganalisis sikap keluarga dalam penerapan program Indonesia sehat dengan pendekatan keluarga di pekanbaru. Keutamaan (urgensi) penelitian ini memiliki aspek pengembangan ilmuk eperawatan yaitu dalam rangka mencari pemecahan masalah penerapan dan penyelenggaraan program Indonesia sehat dengan pendekatan keluarga di pekanbaru yang masih sangat rendah.

\section{METODE PENELITIAN}

Jenis penelitian desktiptif analitik dengan pendekatan cross sectional, yaitu suatu metode penelitian yang dilakukan dengan tujuan utama untuk membuat gambaran atau deskripsi tentang suatu keadaan secara objektif variabel yang diteliti. Metode deskriptif sering digunakan dalam program pelayanan-pelayanan kesehatan.

Penelitian dilaksanakan kepada masyarakat di Wilayah Kerja Puskesmas Sail Pekanbaru dikarenakan dari data yang dilaporkan oleh Dinas Kesehatan Pekanbaru Tahun 2017 didapatkan bahwa masyarakat di wilayah kerja Puskesmas Sail adalah masyarakat ber-PHBS dengan persentase terendah $(24,85 \%)$ dari 20 Puskesmas di Pekanbaru.

Populasi merupakan keseluruhan dari objek penelitian atau objek yang diteliti (Notoatmodjo, 2010). Populasi dalam penelitian ini adalah seluruh keluarga yang abadi Wilayah Kerja Puskesmas Sail Pekanbaru yaitu 5.216 Rumah Tangga. Setelah dilakukan perhitungan sampel (Notoatmodjo, 2015) didapatkan sampel dalam penelitian ini adalah 100 Rumah Tangga.

Defenisi operasional varibel sikap yaitu respon tetutup keluarga (sebelum berperilaku) terhadap program Indonesia sehat, dengan alat ukur kuesioner dan cara ukur adalah wawancara terstruktur. Instrumen sikap memuat 12 pernyataan sikap keluarga dalam menerapkan program indonesia sehat. Instrumen variabel sikap ini telah dilakukan uji validitas dan realibilitas kepada 30 keluarga di wilayah kerja Puskesmas Rumbai Pekanbaru. Setelah dilakukan uji validitas didapatkan hasil bahwa nilai $r$ tabel dengan responden 30 dan taraf signifikan 5\% adalah 0,361. Semua butir pertanyaan setelah dilakukan uji statistik ( $\mathrm{r}$ hitung) didapatkan adalah $>$ 0,361, maka semua butir pertanyaan instrumen variabel sikap dinyatakan valid. Kemudian instumen ini juga telah dilakukan uji realibilitas dengan hasil adalah nilai $\mathrm{r}$ tabel dengan responden 30 dan taraf signifikan $5 \%$ adalah 0,361 . 
Setelah dilakukan uji statistik didapatkan cronbach alpha 0,895, maka cronbach alpha $>\mathrm{r}$ table yang artinya instrumen dinyatakan realibel atau konsisten. Hasil ukur dari variable sikap ini adalah sikap positif (bila skor jawaban $\geq$ mean $(39,86)$ ) dan sikap negatif (bila skor jawaban $<$ mean $(39,86))$, dengan skala ukur nominal. Hasil penelitian ini diukur dengan analisis univariat.

\section{HASIL DAN PEMBAHASAN}

Analisa univariat digunakan untuk menjelaskan tentang variabel penelitian secara deskriptif. Hasil penelitian adalah sebagai berikut :

Tabel 1.Distribusi Frekuensi Sikap

Keluarga Dalam Penerapan PIS-PK

\begin{tabular}{llcc}
\hline No & $\begin{array}{c}\text { Variabel Sikap } \\
\text { Keluarga }\end{array}$ & $\mathrm{f}$ & $\%$ \\
\hline 1 & Positif & 66 & 66 \\
2 & Negatif & 34 & 34 \\
& Total & 100 & 100 \\
\hline
\end{tabular}

Hasil analisis sikap keluarga tentang penerapan PIS-PK diperoleh bahwa lebih dari separoh persentase keluarga bersikap positif yaitu $66 \%$.

Oxford Advanced Learner Dictionary (dalam Ramdhani, 2008), mengatakan bahwa sikap merupakan cara menempatkan atau membawa diri, merasakan, jalan pikiran, dan berperilaku. Kemenkes (2019), menyebutkan bahwa faktor perilaku memegang peran penting dalam menentukan derajat kesehatan masyarakat. Hal ini sesuai dengan teori klasik Blum (1956), yang menyebutkan bahwa 30\% derajat kesehatan dipengaruhi oleh faktor perilaku. Masri (dalam Widiyanta, 2002), mendefinisikan sikap sebagai suatu kesediaan dalam menanggapi atau berperilaku terhadap sesuatu.

Sikap dibentuk dan dipengaruhi oleh pengalaman pribadi, kebudayaan, dan orang lain yang dianggap penting. Pembentukan sikap tidak terjadi begitu saja, melainkan sikap melalui proses dan tahapan secara terus-menerus, demikian pula dalam mengambil kepetusan kesehatan (Desni, 2011). Sikap yang berhubungan dengan keluarga adalah korelasi kunci dari berbagai proses dan hasil keluarga, termasuk pembentukan keluarga. Sikap Keluarga akan selalu berubah dari waktu kewaktu, tergantung terpaparnya mereka dengan pengetahuan dan orang lain (Hye-Won, 2015) .

Menurut Notoatmodjo (2017), seseorang memiliki sikap yang tidak mendukung (negatif) akan cenderung memiliki tingkatan hanya sebatas menerima dan merespon saja, sedangkan seseorang dikatakan telah memilki sikap mendukung (positif) akan mencapai tingkatan menghargai atau bertanggungjawab karena sikap yang ditunjukkan seseorang merupakan respon bathin dari stimulus berupa materi atau objek.

Sikap negatif seseorang disebabkan belum memahami sepenuhnya tentang hidup bersih dan sehat tersebut, sehingga dalam bersikap dan berperilaku juga tidak maksimal. Sedangkan terbentuknya sikap positif tentang hidup bersih dan sehat juga dipengaruhi oleh pengetahuan seseorang. Maka pengetahuan menjadi faktor yang penting dalam menentukan sikap dan perilaku seseorang (Saini, 2016).

Sikap menggambarkan suka atau tidak sukanya seseorang terhadap obyek. Sikap sering diperoleh dari pengalam sendiri atau dari orang lain. Sikap membuat seseorang mendekati atau menjauhi obyek. Cara seseorang bersikap terhadap nilai-nilai kesehatan, tidak terlalu terwujud dalam suatu tindakan nyata (Notoatmodjo, dalam Daulay, 2018).

Peneliti berpendapat, faktor sikap memang peranan penting atau mempengaruhi seseorang dalam menerapkan PIS-PK untuk menjadikan seseorang atau keluarga menjadi keluarga sehat. Faktor lain yang penting adalah faktor lingkungan, dibuktikan dengan observasi lingkungan dan telaah intsrumen bahwa rumah, kesehatan lingkungan dan motivasi dari tetangga menjadi penting untuk seseorang atau sebuah keluarga dalam menerapkan PIS-PK. 


\section{SIMPULAN}

Simpulan dari penelitian ini didapatkan bahwa lebih dari separoh persentase keluarga bersikap positif tentang PIS-PK. Peneliti berharap untuk selanjutnya dilakukan penelitian tentang efektivitas program Indonesia sehat dan diperbandingkan dengan program kesehatan lainnya. Cara keluarga bersikap dalam menjaga kesehatan anggota keluarganya memegang peranan penting untuk mewujudkan keluarga sehat. Hal ini dikarenakan budaya hidup bersih dan sehat dan memenuhi indikator keluarga sehat harus dapat dimunculkan dari dalam keluarga untuk menjaga kesehatan keluarganya. Keluarga yang bersikap dan memenuhi indikator PIS-PK akan menghasilkan budaya menjaga keluarga dan lingkungan yang bersih dan sehat.

\section{UCAPAN TERIMAKASIH}

Peneliti mengucapkan terimakasih kepada Direktur Penelitian dan Pengabdian Masyarakat Direktorat Jendral Pendidikan Tinggi Republik Indonesia, Ketua Lembaga Layanan Dikti Wilayah X (LLDIKTI X), Ketua STIKes Payung Negeri Pekanbaru, Ketua Lembaga Penelitian dan Pengabdian Masyarakat (LPPM) STIKes Payung Negeri Pekanbaru, Kepala Dinas Kesehatan Kota Pekanbaru, Kepala Puskesmas Rumbai Bukit dan Kepala Puskesmas Sail Pekanbaru.

\section{DAFTAR PUSTAKA}

Azwar. (2005). Sikap Manusia Teori dan Pengukurannya, Edisi ke 2. Jakarta; Pustaka Pelajar.

Chandra, Fauzan, A., \& Aquarista, M. F. (2017). Hubungan Antara Pengetahuan Dan Sikap Dengan Perilaku Hidup Bersih Dan Sehat (Phbs) Pada Siswa Sekolah Dasar (Sd) Di Kecamatan Cerbon Tahun 2016. Jurnal Kesmas (Kesehatan Masyarakat) Khatulistiwa, 4(3), 201. https://doi.org/10.29406 /jkmk.v4i3.849

Daulay, S. (2018). Hubungan Pengetahuan Dan Sikap Ibu Rumah Tangga Dengan PHBS. Jurnal Reproductive Health, 2(3).

Fadhilah. (2015). Teori Psikologi Gestalt.

Diakses

Dari

https://www.kompasiana.

com/naffstradiv13/550090bba333111

e735114d5/teori-Psikologi-Gestalt.

Ford-gilboe, M. (2002). Developing Knowledge About Family Health Promotion by Testing the Developmental Model of Health and Nursing. Journal of Family Nursing, 8(May), 140-156.

Hidayat, A. A. (2007). Metodologi Penelitian Keperawatan \& Teknik Analisis Data. Jakarta; Salemba Medika.

Kemenkes RI. (2016). Permenkes Nomor 39 Tahun 2016 tentang Pedoman Penyelenggaran Program Indonesia Sehat Dengan Pendekatan Keluarga. Jakarta; Kemenkes RI.

Kemenkes RI. (2019). Derajat kesehatan $40 \%$ dipengaruhi lingkungan. Kemenkes RI, 20-21.

Kim, E. H. W., \& Cheung, A. K. L. (2015). Women's Attitudes Toward Family Formation and Life Stage Transitions: A Longitudinal Study in Korea. Journal of Marriage and Family, $77(5)$, 1074-1090. https://doi.org/10.1111/jomf.12222

Laelasari, E., Anwar, A., \& Soerachman, R. (2017). Evaluasi Kesiapan Pelaksanaan Program Indonesia Sehat dengan Pendekatan Keluarga. Jurnal Ekologi Kesehatan, 16(2), 57-72. https://doi. org/10.22435/jek.v16i2.7835.57-72

MacAbasco-O'Connell, A., \& Fry-Bowers, E. K. (2011). Knowledge and perceptions of health literacy among nursing professionals. Journal of Health Communication, 16(SUPPL. 3), 295-307. https://doi.org/10.1080/10810 730.2011 .604389 
Notoadmodjo, S. (2010). Promosi

Kesehatan; Teori dan Aplikasi Edisi Revisi 2010. Penerbit; Rineka Cipta.

Notoadmodjo, S. (2017). Metode Penelitian Kesehatan. Jakarta: Penerbit Rineka Cipta.

Rahardjo, S., \& Kusumawati, E. (2011). Hubungan Tingkat Pendidikan Dan Pengetahuan Dengan Perilaku Keluarga Sadar Gizi (Kadarzi) Pada Masyarakat Perkotaan Dan Perdesaan Di Kabupaten Banyumas. Jurusan Kesehatan Masyarakat Fakultas Kedokteran Dan Ilmu-Ilmu Kesehatan Universitas Jenderal Soedirman, 4(2), 150-158.

https://doi.org/10.1017/CBO9

781107415324.004

Sarwono, S. (2004). Sosiologi Kesehatan: beberapa konsep beserta aplikasinya, Cetakan Ketiga,. Yogyakarta Gajahmada University Pers.

Widiyanta, A. (2004). Sikap Terhadap Lingkungan Alam: Tinjauan Islam Dalam Menyelesaikan Masalah Lingkungan. Fakultas Kedokteran, Universitas Sumatera Utara, 1-16. 